population of Akhal-tekke consists of Tekke-Turcomans (8400 kibitkas, about 42,000 souls), with some II60 Persians and Tartars, 930 Armenians, and 340 Russians, without families. Askabad, the chief town of this district, has already an important trade. The inhabitants of the Krasnovodsk and Manghishlak districts, on the contrary, are nearly all nomads, and their chief towns, Krasnovodsk and Alexandrovsk, are miserable hamlets with less than 400 inhabitants each. The oasis of Merv, with its 32,000 kibitkas, is well peopled. The bazaars of the chief town are very animated, 8000 to 10,000 people gathering there twice a week. Since 1785, when the Sultan-bend dam on the Murghab was destroyed by the Ameer Murad Khan, the area of the oasis has much diminished, and it occupies now only a length of 160 miles, and a width of some 13 miles. The town Bairam-kalæ was abandoned for want of water. The Tekke Turcomans, who have inhabited the oasis since 1857 , when they drove away the Saryks, are divided into two stems, the Okhtamyshs and the Tokhtamyshs. The richer of them live in felt tents, while the poorer ones make huts of clay of the same shape as the felt tents. These settlements and villages are not permanent, and may be changed at the first signal of alarm. In fact the population is too numerous for the watered area. As to the fertile oasis of Tejen, on the Heri-rud, it was formerly visited only in the summer. It has now some 7500 Tekke inhabitants, who have immigrated from Merv, Akhal, and Atek.

Mr. Shipley, the American Consul at Auckland, New Zealand, reports to the State Department at Washington, the following facts about a new volcano in the Pacific Ocean :- "At daylight on October 13 we observed dense volumes of steam and smoke clouds ascending. We sailed sufficiently near to see that it was a submarine volcanic eruption. Considering that it was not prudent to approach any nearer that night, we lay to until morning. We then approached to about a distance of two miles. I have not words to express my wonder and surprise at its changing splendour. Eruptions take place every one or two minutes, changing in appearance every second, like a dissolving view. I can only say that it was one of the most awfully grand sights I ever witnessed on the high seas. As near as I was able to calculate the position of the volcano, it is about fourteen miles from the island of Honga Tonga. As to the size of the island thrown up, I am unable to state it correc:ly, there being so much steam and cloud hanging over it; but I judge it to be at least two or three miles long, and 60 feet high, in lat. $20^{\circ} 2 \mathrm{I}^{\prime} \mathrm{S}$., long. $175^{\circ} 2 \gamma^{\prime} \mathrm{W}$."

\section{THE PARIS ACADEMY OF SCIENCES}

T'HE yearly meeting of the Paris Academy of Sciences took place in the large hall of the Institut on December 2 . Rear-Admiral Julien de la Gravière was in the chair. He read a short paper summarising the eloges of eight members who died during the past twelve months. This number is unusually large in a body of sixty-six.

M. Bertrand delivered two addresses on M. Lagourneria, a geometer, and M. Combes, an engineer, who died some years ago, after having enjoyed the academical honours during many years.

The number of prizes delivered by the Academy is increasing yearly, not less than thirty-three being offered for competition in 1886. The total of the sums to be awarded is more than $3000 \%$, exclusive of some of which the value is to be determined according to the merits of competitors, and the Bréant Prize for a cure for cholera. Dr. Ferran was not even mentioned in the verdict, and the interest of the 4000 l. was given to several writers on the etiology of cholera.

Some of the prizes for 1885 were not awarded, for want of competition, although, except a very few, they are open to every nation, and memoirs can be written in any language as well as in French. A large number of prizes were not delivered for want of merit in the contributions sent. Some of them were awarded to scientific writers who have publıshed volumes on topics connected with the subject-matters. Of this last class we may mention, inler alia, "Memoire sur la Marche et l'Extension du Choléra Asiatique des Indes Orientales," \&c., by Dr. Mahé, representing France at Constantinople; "Contributions à l'Etude de la Fièvre Typhoïde," by Dr. Pietro Santo ; "Statistique de l'Industrie minérale et des Appareils à Vapeur en France et en Algérie," by M. Keller ; "Contributions à l'Etude statistique du Suicide en France," by Dr. Jules Socquct; "Histoire de l'ancienne Académie de Marine de Brest," by M. Donneaud du P'lan, Librarian of the Navy at Dieppe.

Amongst the most important prizes awarded we notice the following :-

M. Amsler Laffon, of Shaffhouse, for his instrument for polar planimetry, as presented by Mr. Scott Russell to the Institution of Naval Architects in 1880 (Monthyon Medallist for Mechanical Arts).

M. Colladon, of Geneva, for the application of compressed air as a motive power in tunnelling Mont Cenis (Fourneyron Medallist).

M. Thollon, for mapping the solar spectrum in the Bischoffsheim Observatory, Nice (Lalande).

Dr. Spörer, of the Potsdam Astro-Physical Observatory, for his studies on solar spots (Voltz).

Dr. Edlund, member of the Academy of Sciences of Stockholm, for his memoir on the origin of electrical tension of the atmosphere. He considers this tension to be produced by the rotation of the earth, which is a magnet. The soil being made negative, the atmosphere becomes positive by induction. The difference of tension resulting from his calculations is 223 volts per kilometre altitude. No less than twelve memoirs were sent -five in French, four in German, and three in English (Boydron Prize). The memoir of Dr. Edlund had been already printed and published.

M. Gernez, for his discoveries in rapid solidification of supersaturated liquids.

M. Halphen, a major in the French Artillery, took the Petit d'Ormay Prize for the ensemble of his mathematical work and principally the solution of the following problem:-Trouver les équations différentielles qui se reproduisent par une substitution linéaire.

The Monthyon Prize for discoveries in connection with unhealthy arts has been given to M. Chamberland, chief assistant of M. Pasteur, who invented a filter in chinaware which stops even microbes.

The Government Prize was given to M. Joannes Chatin for his study of the sensation organs of invertebrate animals.

The Cuvier Medallist for this year is Prof. Van Beneden, of the Louvain University, for half a century of work in physiology.

\section{THE NEW ZEALAND INSTITUTE}

T'HE volume of Transactions of the New Zealand Institute for 1884 was issued to the members in May of the present year. It is edited by Dr. Hector, and contains fifty-five memoirs, which, read before the various affiliated societies, have been deemed worthy, by the Governors of the Institute, of publication. While the papers on biological subjects occupy threefourths of the space devoted to the transactions, those on geology are but few in number. Among the more important of the zoological memoirs may be mentioned the following :- "Descriptions of New Zealand Micro-Lepidoptera," by E. Meyrick (pp. 68-I49). In continuation of his previous memoirs we have here full details and an analysis of the following families :Scopariadæ; while no species of this family is common to New Zealand and Australia, the author has included in his memoir descriptions of the known Australian species of the genera Scoparia, Tetraprosopus and Xeroscopa. Fifty-eight species of the first and sixteen species of the last genus are described. Pyralidæ: Hydrocampidæ; these families are each represented by a single species, neither of which is, in a strict sense, indigenous, Asopia farinalis being introduced from Europe. The representative of the latter family, Hygraula nitens (Butl.), being regarded as a recent migrant from south-east Australia. Pterophoridæ; eleven species are described: one is closely allied to a European form, one is Australian; the other nine are all endemic. In a supplement a number of additions to the previously-published list of species of Crambidæ and Tortricidæe are described. "Further Notes on Coccidæ," by W. M. Maskell. The author comments on our notice this time last year of the roughness of the plates in Vol. XVI. While we agree with him that all biologists are not artists, yet we venture to think that it is not too much to expect that there should be one artist at Wellington who could execute plates in a style worthy not only of the New Zealand Institute, but in keeping with the excellent typography of the volume. Thus, the very "lettering "of the plates in the present volume is not only bad, but misleading, Vol. XIV. being misprinted for Vol. XVII., and Plate 
8 for Plate 7. We notice, however, an improvement in the lithography. In his notes Mr. Maskell describes several new species, and advances our knowledge of the New Zealand fauna very considerably. In a paper on the spiders of New Zealand, Mr. A. T. Urquhart describes and figures a great many new species, chiefly from the neighbourhood of Auckland. Prof. Jeffrey Parker gives notes on the skeleton and baleen of a Fin Whale (Balcenoptera musculus), and Mr. S. Mieson gives some interesting details about a plague of rats in Nelson.

Among the botanical memoirs may be noted those of Mr. T. Kirk, on the flora of Stewart Island. Prefaced by a short sketch of the island, and the facts previously known as to its natural history, Mr. Kirk gives the results of his investigations of its flora made during two visits in January, 1882 , and in January, 1884. So far as at present known the flora of the island comprises about 380 species of Phrnosams, and nearly 70 species of Pteridophytes. The area of the island is estimated at 640 square miles. Attention was at once attracted by the blaze of crimson presented by the flowers of Metrosideros lucida, often flecked by the beautiful pale racemes of Weinmannic racemosa. Veronica salicifolia occurred by the side of watercourses, but was far from common. The soil was often carpeted with a compact growth of the charming liliaceous plant Callixene parviftora, with its elegant drooping flowers. The terrestrial orchids formed a marked feature in some parts of the forest. Coryanthes oblonga and C. rivularis produced their attractive flowers literally by thousands. Arborescent ferns were abundant, the most abundant being Dicksonia squarrosa and Hemitelea smithii. The crest of Mount Anglem, the highest peak of the island, was ascended. The weather, unfortunately, was unfavourable, the driving snow obscuring the prospect. A splendid Alpine flora was discovered. Dracophyllum muscoides formed a compact dark green sward gemmed with white flowers; several species of Coprosma, Ranunculus lyalii, the beautiful Ourisia sessiliflora, also $O$. coespitosa.

On exposed portions of the coast on both sides of the island Olearia angustifolia was found; it is one of the grandest of flowering plants. Varying in size from shrubs of about 6 feet high, to a tree of 20 feet, the snowy ray florets, with the dark purple of those of the disk of the innumerable flower heads, set off by the dark, deep, glossy green foliage, form a never-tiring source of attraction, while the aromatic odour exhaled is of a grateful type. $O$. trailii, also another splendid species, but sparingly occurred. A list of the ferns and fern allies is given. Todea superba grows luxuriantly; one specimen was examined which had a stout stem some i8 feet high, from which arose a dense crown of nearly erect fronds, with drooping tips; some of these were several years old and were between four and five feet in length, of a deep blackish green. Mosses and large frondose Hepaticæ also abounded.

Mr. Cheeseman, Mr. Colenso, and Mr. Petrie, continue their descriptions of species new to science and to New Zealand.

In the section devoted to geology Capt. F. W. Hutton describes a large number of new Tertiary shells; Dr. J. von Haast has notes on the geological structure of the Southern Alps of New Zealand, in which he criticises Dr. Hector's recently-published map of this district; and Dr. Hector has a note on the geological structure of the Canterbury Mountains, in which he very temperately justifies changes in his views of geological periods as based on the progress of his knowledge of facts. Mr. James Parks's account of the ascent of Mount Franklin will be read with interest; though occupying a central position in the province of Nelson, it does not seem to have been before ascended. The Waiau Gorge is described as one of the most wonderful in New Zealand. On both sides the mountains frequently rise by a succession of steep, rugged precipices to a height of 3500 feet over the river. About 6050 feet high a small area of glacier ice was found, probably all that now remains of the great Waiau Glacier. Small patches of red snow were found; at 6500 feet in height permanent snow-fields were met with, and the top of the range, described as a mere razor-back, only a few feet wide, and composed of loose, angular, and slab-like rocks was found to be 7500 feet high. The highest peak, by aneroid measure ment, was 350 feet higher. A list of the Alpine plants collected on the occasion, and determined by Mr. J. Buchanan, is appended.

It will be judged from this short notice that this volume, edited by Dr. Hector, is one coming in no way short of its predecessors and that it reflects credit on the scientific workers of New Zealand.

\section{UNIVERSITY AND EDUCATIONAL INTELLIGENCE}

OXFORD.-A Fellowship will be filled up in Lincoln College in January next.

The Examination will be in the subjects of Animal Physiology and Animal Morphology; and candidates are invited to send in any treatises or theses that they may have written or published in special branches of one or both of these subjects.

Candidates should communicate at once with the Rector, who will furnish them with full information as to the conditions and tenure of the Followship.

CAMBRIDGE. - Another development from Prof. Stuart's School of Engineering is probable. The Special Board for Physics and Chemistry, considering the number of students of engineering warrants such a step, propose for their benefit an Honours Examination, to be connected with the Natural Sciences Tripos. Certain branches of Mathematics, useful alike for students of Engineering, Physics, and Chemistry, are to be introduced into an examination alternative with the first part of the Natural Sciences Tripos. Papers should be included on Principles of Measurement, Theory of Structures, Properties of Matter, Principles of Mechanism, and other branches of Physics and Chemistry, and there should be practical work in Engineering, as well as in Physics and Chemistry, each candidate being required to pass the practical examination in at least one of these three subjects. A student passing this examination with credit in his third year should be entitled to a degree in honours.

A second higher Examination is proposed, to be concurrent with the second part of the Natural Sciences Tripos, in the same subjects as above-mentioned, and the examiners should be at liberty to set questions involving the Mathematics of the first Examination, and in those parts of Mineralogy which belong to Physics and Chemistry. Other conditions are similar to those of the Natural Sciences Tripos. The Special Board for Mathematics has expressed its general approval of the scheme.

At St. John's College E. H. Hankin and F. S. Locke, both of St. Bartholomew's Hospital Medical School, have been elected to Exhibitions of $50 \%$. a year in Natural Science. In Mathematics, F. M. Monro, King William's College, has been elected to a Foundation Scholarship of 80 l. a year; A. G. Cooke, City of London School, to a Minor Scholarship of $75 l$. a year; A. Kahn, Middle Class School, Cowper Street, E.C., and J. A. Lawrenson, Liverpool Institute, to Minor Scholarships of 50 l. a year; W. H. Box, University College, Aberystwith, and S. Humphries, Middle Class Sichool, Cowper Street, E.C., to Exhibitions of $40 l$. a year for three years.

\section{SCIENTIFIC SERIALS}

The Fournal of Anatomy and Physiology for October (vol. $\mathrm{xx}$. part I) contains :-On the anatomy of the muscles, ligaments, and fascia of the orbit, by C. B. Lockwood (plate I). Two cases of an abnormal coronary artery of the heart arising from the pulmonary artery, by Dr. H. St. John Brooks (plate 2). - On a second bursa connected with the insertion of the biceps, \&c, , by A. Ward Collins.-Abnormalities of the lobes of the human lung, by A. E. Maylard.-On the nature of ligaments, part 4, by J. Bland Sutton (plate 3).-Vital relations of microorganisms to tissue elements, by Drs. G. S. Woodhead and A. W. Hare.-The blood-forming organs and blood-formation : an experimental research, part ii., by Dr. J. Lockhart Gibson. The relationship of urea-formation to bile-secretion : an experimental research, by Dr. Noel-Paton. - The index of the pelvic brim as a basis of classification; and on the anatomy of Sowerby's whale, by Prof. W. Turner (plate 4).

The Quarterly Fournal of Microscopical Science for October contains:-On the chromatology of the blood of some invertebrates, by Dr. C. A. MacMunn (plates 33 and 34). Among other pigments referred to, the colouring-matter of the perivisceral fluid of Strongylocentrotus lividus, named echinochrome, is described in detail.....-On the cephalic appendages of the gymnosomatous Pteropoda, and especially of Clione, by Dr. Pau Pelseneer (plate 35). The cephalic appendages in Clione, Clionopsis, and Pneumodermon are described. In Clione there are tentacles, properly so called, and buccal cones. In Pneumodermon there are tentacles and two acetabuliferous buccal appendages, and in Clionopsis only tentacles are found. While the author leaves the function of the buccal cones in Clione 